\title{
Protective Effect of Uridine on Cornea in a Rabbit Dry Eye Model
}

\author{
Joo Youn Ob, ${ }^{1,2}$ Youn Seok In, ${ }^{1,2}$ Mee Kum Kim, ${ }^{1,2}$ Jung Hwa Ko, ${ }^{2}$ Hyun Ju Lee, ${ }^{2}$ \\ Ki Cheul Shin, ${ }^{3}$ Sang Mok Lee, ${ }^{1,2}$ Won Ryang Wee, ${ }^{1,2}$ Jin Hak Lee, ${ }^{1,2}$ and Myunggyu Park ${ }^{4}$
}

Purpose. To investigate the effect of uridine on cultured human corneal epithelial cells and keratocytes in vitro and to evaluate whether the application of uridine-containing eye drops could improve ocular surface health in an in vivo dry eye model.

Methods. Uridine was added to cultured epithelial cells $(3 \times$ $10^{4}$ cells/well) and keratocytes $\left(1 \times 10^{4}\right.$ cells/well $)$ at various concentrations $(0.5-50 \mu \mathrm{M})$. Cytotoxicity was tested with the use of MTT assay, and the cells were assessed for apoptosis with the use of flow cytometry. Expressions of hyaluronic acid (HA), glycosaminoglycan (GAG), nitric oxide (NO), and matrix metalloproteinase (MMP)-9 were measured. In vivo, the degree of reepithelialization was assessed after topical application of uridine $(100 \mu \mathrm{M})$ in a rabbit corneal wound model. Changes in tear production and conjunctival goblet cell counts were investigated after instillation of various concentrations of uridinecontaining eye drops in a rabbit dry eye model.

Results. In vitro, uridine showed no cellular toxicity. It increased the biosynthesis of HA and GAG and reduced MMP-9 levels in cultured corneal epithelial cells and keratocytes. In vivo, uridine enhanced corneal wound healing and significantly increased the number of conjunctival goblet cells in rabbits.

Conclusions. Uridine can restore the health of the ocular surface in a rabbit corneal wound and dry eye model. (Invest Ophthalmol Vis Sci. 2007;48:1102-1109) DOI:10.1167/iovs.060809

$\mathrm{D}$ ry eye syndrome is a common disorder that affects approximately $10 \%$ to $20 \%$ of the adult population worldwide. ${ }^{1,2}$ Dry eye is associated with a decrease in tear aqueous production and abnormalities of the lipid, protein, and mucin profiles. These changes cause desiccation of the ocular surface, leading to epithelial damage as a result of inflammation on the surface. Although dry eye develops from multiple etiologies, it is most often treated with artificial tear supplementation,

From the ${ }^{1}$ Department of Ophthalmology, Seoul National University College of Medicine, Seoul, Korea; ${ }^{2}$ Seoul National University Hospital Clinical Research Institute, Seoul, Korea; ${ }^{3}$ Department of Ophthalmology, Kunkuk University Hospital, Seoul, Korea; and ${ }^{4} \mathrm{MD}$ Bioalpha, Suwon, Korea.

Presented at the 78th annual meeting of the Association for Research in Vision and Ophthalmology, Fort Lauderdale, Florida, May 2006.

Supported by Seoul National University Hospital research fund Grant 03-2005-002.

Submitted for publication July 14, 2006; revised October 30, 2006; accepted January 24, 2007.

Disclosure: J.Y. Oh, None; Y.S. In, None; M.K. Kim, None; J.H. Ko, None; H.J. Lee, None; K.C. Shin, None; S.M. Lee, None; W.R. Wee, None; J.H. Lee, None; M. Park, MD Bioalpha (F)

The publication costs of this article were defrayed in part by page charge payment. This article must therefore be marked "advertise$m e n t "$ in accordance with 18 U.S.C. $\$ 1734$ solely to indicate this fact.

Corresponding author: Mee Kum Kim, Department of Ophthalmology, Seoul National University College of Medicine, 28 Yongondong, Chongno-gu, Seoul 110-744, Korea; kmk9@snu.ac.kr. which is palliative in nature and provides relief for only a short period. Nevertheless, only two pharmacologically active agents are available to treat this condition-cyclosporine A (Restasis; Allergan Inc., Irvine, CA), which reduces inflammation, and hyaluronic acid (HA), which promotes epithelial healing. ${ }^{3,4}$ Uridine is transformed to uridine $5^{\prime}$-triphosphate (UTP) by uridine kinase in vivo. UTP, as a full agonist at the $\mathrm{P}_{2} \mathrm{Y}_{2}$ receptor, ${ }^{5}$ is known to stimulate mucin secretion in various tissues such as conjunctiva, ${ }^{6}$ nasal epithelial cells, ${ }^{7}$ and tracheal gland cells. ${ }^{8}$ One report suggests that elevated uridine $5^{\prime}$ diphosphate (UDP)-glucose contributes to an increase in the synthesis of intrinsic HA, ${ }^{9}$ which promotes cell migration, stabilizes the ocular surface epithelial barrier, and controls localized inflammation in patients with keratoconjunctivitis sicca. ${ }^{10-12}$

In the present study, we investigated the effect of uridine on cultured human corneal epithelial cells and keratocytes in vitro and evaluated whether the application of uridine-containing eye drops could improve ocular surface health in an in vivo dry eye model.

\section{Materials ANd Methods}

This study was approved by the Institutional Review Board and the Institutional Animal Care and Use Committee of the Seoul National University Hospital and was performed in accordance with the ARVO Statement for the Use of Animals in Ophthalmic and Vision Research.

\section{Human Corneal Epithelial Cells and Keratocytes Culture}

In accordance with the tenets of the Declaration of Helsinki and with proper informed consent, 20 human corneoscleral rims were obtained 5 days after harvest from the Northwest Lions Eye bank within 8 hours of penetrating keratoplasty. Each tissue sample was treated with $0.05 \%$ trypsin and $0.01 \%$ EDTA at $37^{\circ} \mathrm{C}$ and then was collected four times at 20-minute intervals. NIH/3T3 (ATCC, Manassas, VA) cell lines were used as a feeder layer and were treated with $4 \mu \mathrm{g} / \mathrm{mL}$ mitomycin $\mathrm{C}$ (Sigma, St. Louis) at $37^{\circ} \mathrm{C}$ for 2 hours and were plated to $80 \%$ confluence for coculture with epithelial cells. Suspended cells seeded in $1.5 \times 10^{4}$ cells $/ \mathrm{cm}^{2}$ on the $3 \mathrm{~T} 3$-pretreated plates were primarily cultured with the SHEM medium at $37^{\circ} \mathrm{C}$ in a carbon dioxide incubator for 2 weeks. Culture medium was a mixture of Dulbecco modified Eagle medium (DMEM) and Ham F12 medium (1:1 mixture) and included fetal bovine serum (FBS; 10\%), insulin $(5 \mathrm{mg} / \mathrm{mL})$, cholera toxin $(0.1$ $\mathrm{nM})$, epidermal growth factor $(10 \mathrm{ng} / \mathrm{mL})$, and penicillin-streptomycin (PS; $50 \mathrm{IU} / \mathrm{mL}$ ). For the keratocyte culture, the remaining human limbal tissues were treated with $1.2 \mathrm{U} / \mathrm{mL}$ dispase II for 16 hours at $4^{\circ} \mathrm{C}$. Next, $200 \mathrm{U} / \mathrm{mL}$ type I collagenase $(5 \mathrm{~mL})$ was applied to the neutral protease (Dispase)-treated tissues at $37^{\circ} \mathrm{C}$, and keratocytes were collected every 30 minutes after shaking three times. Collected cells were cultured in DMEM/F12 (1:1) with $10 \% \mathrm{FBS}$ and $1 \% \mathrm{PS}$ at $37^{\circ} \mathrm{C}$ in a carbon dioxide incubator for 2 weeks.

\section{Assessment of the Effect of Uridine on Cultured Corneal Epithelial Cells and Keratocytes In Vitro}

After 2 weeks of cultivation, epithelial cells $\left(3 \times 10^{4}\right.$ cells/well $)$ and keratocytes $\left(1 \times 10^{4}\right.$ cells/well $)$ were harvested and plated on collagen 

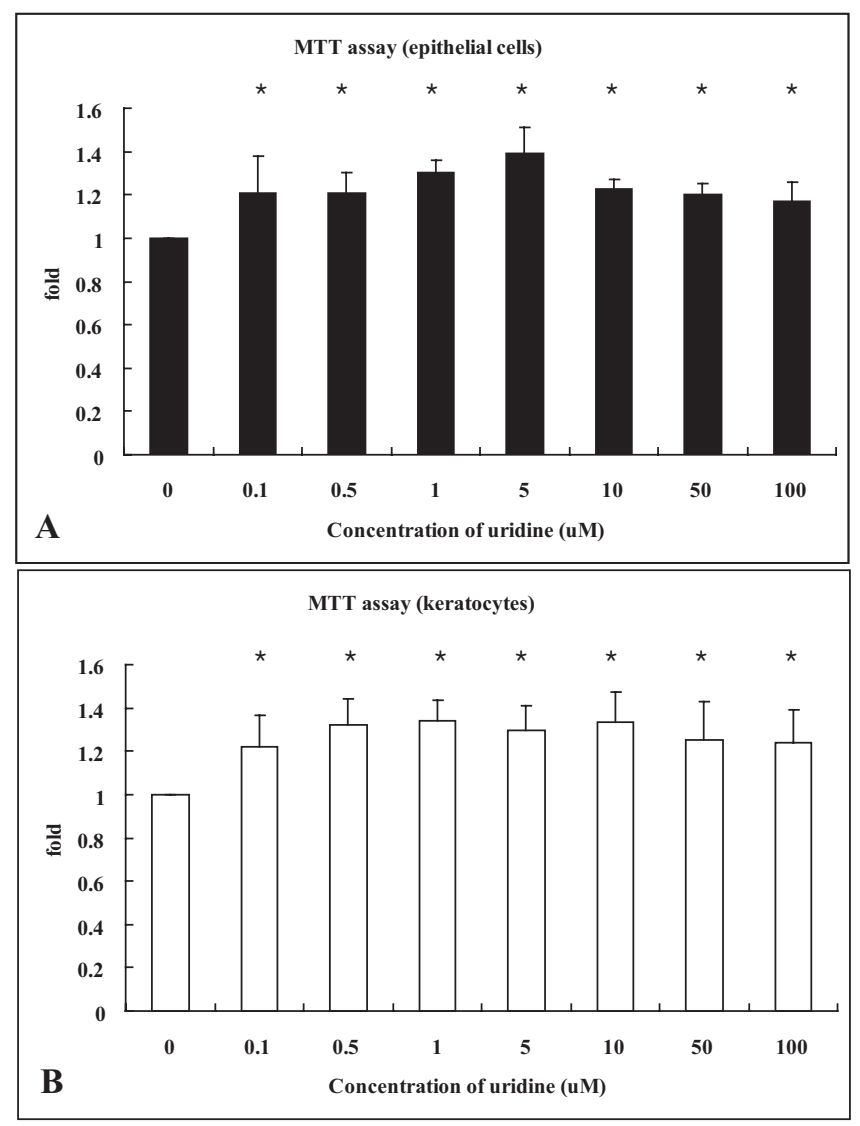

FigURE 1. Cytotoxicity test using MTT assay at various concentrations of uridine (0.1-100 $\mu \mathrm{M})$ in cultured corneal epithelial cells (A) and keratocytes (B). Uridine had no cellular toxicity at any concentrations examine. Data are expressed as mean $\pm \mathrm{SD} .{ }^{*} P<0.05$ (Student's $t$ test)

IV ( $5 \mu \mathrm{g} / \mathrm{mL}$ )-coated 96-well and plain 96-well plates, respectively, and were stabilized for 1 day before additional experiments.

Cytotoxicity Test. We added $10 \mu \mathrm{L}$ uridine to cultured epithelial cells and keratocytes at various concentrations (0.1-100 $\mu \mathrm{M})$. After 48 hours, the viable cells were quantitated by MTT (3-[4,5-dimethylthiazol-2-yl]-2,5-dephenyl tetrazolium bromide; Roche, Mannheim, Germany) assay according to a protocol recommended by the manufacturer.

Apoptosis Assay. Epithelial cells $\left(4 \times 10^{5}\right.$ cells) and keratocytes $\left(1 \times 10^{5}\right.$ cells), treated with $50 \mu \mathrm{M}$ and $100 \mu \mathrm{M}$ uridine for 48 hours, were permeabilized and stained with propidium iodide (PI; $0.1 \mu \mathrm{g} / \mathrm{mL}$ ) and analyzed by flow cytometry (FACSCalibur; BD Biosciences, Oxford, UK). Apoptotic cells showed low DNA stainability resulting in a distinct, quantifiable region below the $G_{0} / G_{1}$ peak, and then the percentage of apoptotic cells was calculated in the sub- $G_{0} / G_{1}$ peak region.

In Vitro HA Biosynthesis Assay. Various concentrations of uridine $(0.5-50 \mu \mathrm{M})$ were added once to cultured epithelial cells and keratocytes $(10 \mu \mathrm{L})$ at $50 \%$ confluence; after 48 hours, HA was measured in the supernatant by an enzyme-linked immunosorbent assay (ELISA; Molecular Device, Hokkaido, Japan) using biotin-HA binding protein (B-HABP; Sigma). The principle on which the method was based is that HA binds strongly to B-HABP, which was prepared from cartilage proteoglycans. HA was immobilized on polyvinyl chloride plates precoated with poly-L-lysine. The unknown sample or the HA standard, together with excess B-HABP, was then added. The B-HABP that bound to the immobilized HA was incubated with the enzymeconjugated avidin (e.g., alkaline phosphatase), and the color that developed after enzyme substrate (e.g., p-nitrophenyl phosphate) was added was analyzed by light absorption using an ELISA reader (Molec- ular Device). We quantitated the amount using the standard curve of absorption and recalculated them by the ratio of the concentration in treated groups compared with the concentration in controls.

Glycosaminoglycan Biosynthesis Assay. Next, $1 \mathrm{~mL}$ dimethyl methylene blue dye was added to the sample $(100 \mu \mathrm{L})$, including cultured epithelial cells and keratocytes treated with uridine for precipitation of sulfated GAG. After the supernatant was removed and a dissociation reagent $(1 \mathrm{~mL})$ was added, the concentration of GAG was determined by ELISA kits (Blyscan; Biocolor Ltd., Newtownabbey, Northern Ireland) for GAG in accordance with the manufacturer's protocol.

In Vitro Nitric Oxide Assay. $\mathrm{H}_{2} \mathrm{O}_{2}(100 \mu \mathrm{M}, 10 \mu \mathrm{L})$, including cultured epithelial cells and keratocytes with uridine, was added to the sample $(100 \mu \mathrm{L})$ for oxidative stress, and the Griess reagent $(100 \mu \mathrm{L}, 4$ $\mathrm{ng} / \mathrm{mL}$ ) was used for colorimetric determination of $\mathrm{NO}_{2}{ }^{-}$as a measure of total plasma NO.

In Vitro Matrix Metalloproteinase-9 Assay. Total RNA was isolated from corneal epithelial cells with uridine by acid guanidinium thiocyanate-phenol-chloroform extraction according to a previously described method. ${ }^{13}$ PCR primers for matrix metalloproteinase (MMP)-9 and glyceraldehyde-3-phosphate dehydrogenase (GAPDH) were designed from published human gene sequences (552 bp; sense, ATC CAG TTT GGT GTC GCG AGC; antisense, GAA GGG GAA GAC GCA CAG CT). Reverse transcription-polymerase chain reaction (RT-PCR) was performed with a RT-PCR kit (TaKaRa; Takara, Shiga, Japan) to evaluate the expression of these MMP-9 genes by corneal epithelial cells with a housekeeping gene, GAPDH, as the internal control. ${ }^{14}$ Expression levels of
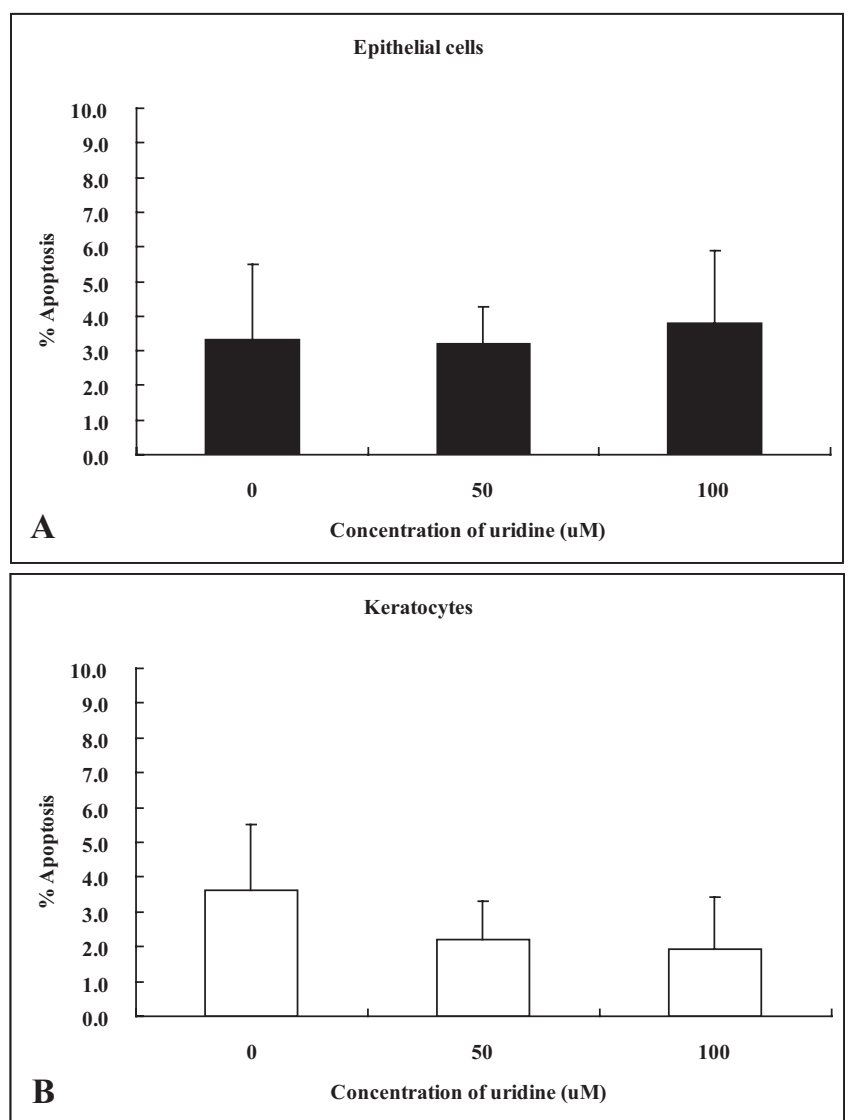

Figure 2. Propidium iodide staining and detection by flow cytometry. Cultured epithelial cells (A) and keratocytes (B) were added with $50 \mu \mathrm{M}$ and $100 \mu \mathrm{M}$ uridine for 48 hours. With the use of flow cytometry, apoptotic cells were identified in a distinct, quantifiable region below the $G_{0} / G_{1}$ peak as the sub- $G_{0} / G_{1}$ peak. No differences were observed in the amount of apoptosis between the uridine-treated cells and the untreated control. Data are expressed as mean \pm SD. 

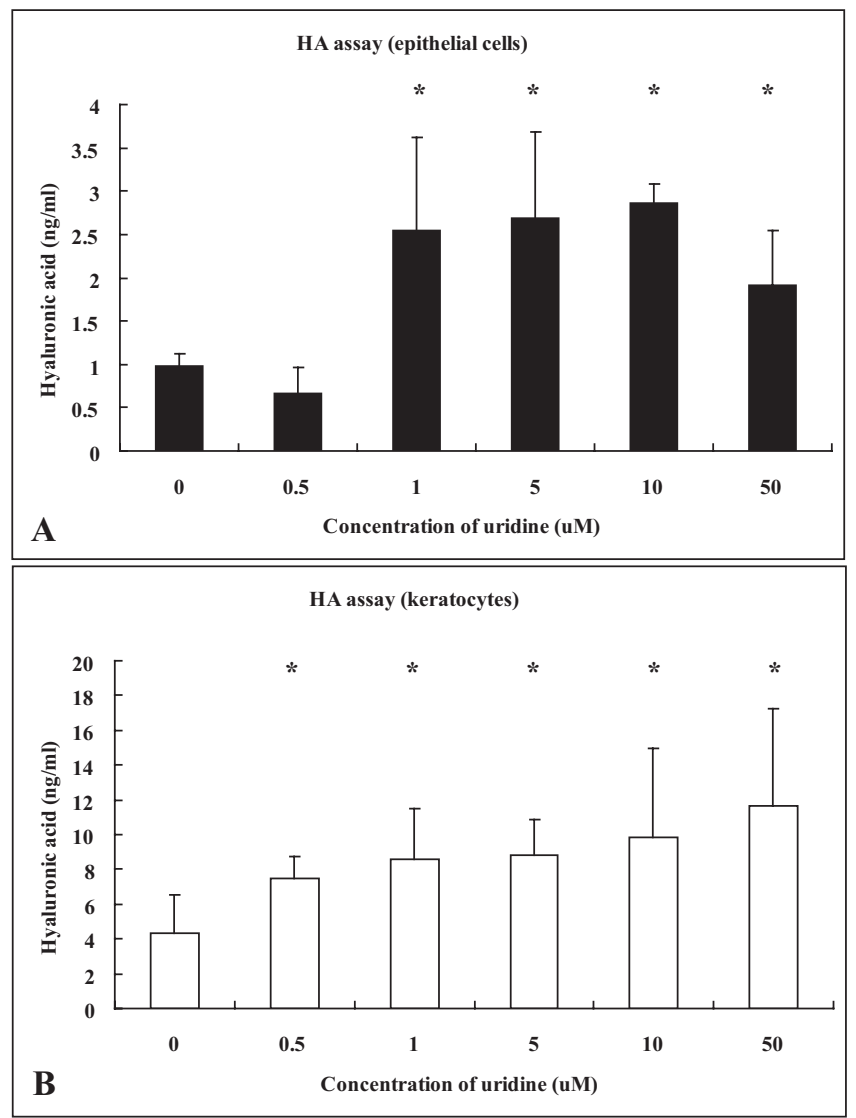

FIGURE 3. HA assay using an enzyme-linked immunosorbent assay with biotin-HA binding protein at various concentrations of uridine $(0.5-50.0 \mu \mathrm{M})$ in cultured epithelial cells (A) and keratocytes (B). HA increased significantly in uridine-added epithelial cells and keratocytes. Data are expressed as mean $\pm \mathrm{SD} .{ }^{*} P<0.05$ (Student's $t$ test).

MMP-9 transcripts were semiquantified with an image analyzer and densitometry (Tina 2.0; Raytest, Straubernhardt, Germany).

\section{Assessment of the Effect of Uridine on Corneal Wound Repair in a Rabbit by Topical Eye Drops Application}

Establishment of Corneal Epithelial Wound Model in a Rabbit Using Mechanical Scraping. Twenty-four adult New Zealand White rabbits (male, $2-3 \mathrm{~kg}$ ) were used. The cornea was marked with 7.0-mm trephine, and the epithelium was mechanically scraped with a cotton-tip applicator after application of $90 \%$ ethyl alcohol for 20 seconds

Assessment of Reepithelialization. Uridine $(100 \mu \mathrm{M})$ and PBS solution were administered four times per day in the study group and in controls, respectively ( $n=12$ in each group). Photographs were taken 1, 2, 3, 4, and 5 days after epithelium removal, and the ratio of the epithelial defect area to the total corneal area was calculated with an image analyzer (Image Pro Plus; Media Cybernetics, Silver Spring, MD)

\section{Assessment of the Effect of Uridine in a Rabbit Dry Eye Model by Topical Eye Drops Application}

Establishment of a Short-term Rabbit Dry Eye Model. Twenty-three adult New Zealand White rabbits (male, 2-3 kg) were injected with $0.5 \mathrm{~mL}$ concanavalin A (Con A; $10 \mathrm{mg} / \mathrm{mL}$; Sigma). Con A was injected twice, with a 3-day interval, through the fornix into the lacrimal gland of 13 rabbits $^{15} ; 10$ other rabbits were used for controls. Tear production was measured by the Schirmer test each day, and impression cytology was performed on the superior conjunctiva on day 3 and day 10 after the first Con A injection. Lacrimal glands of three rabbits in the Con A group were acquired and sectioned 3 days after injection and were evaluated histologically with hematoxylin and eosin (H\&E) staining.

Application of Uridine-Containing Eye Drops. Sixty adult New Zealand White rabbits (male, $2-3 \mathrm{~kg}$ ) were used. Uridinecontaining eye drops were formulated in normal saline at concentrations of $1 \%, 5 \%$, and $10 \%$. Each of the concentrations of topical uridine and $(0.1 \%$ HA; Hyalein; Santen, Osaka, Japan) was topically applied randomly to one eye beginning 3 days after the first injection of Con A and consecutively for 7 days thereafter $(n=5$ in the $1 \%$ and $10 \%$ uridine groups; $n=10$ in the hyaluronic acid group; $n=20$ in the 5\% uridine group). In the group used as controls, no eye drops were administered in another 20 eyes from 20 rabbits after Con A injection.

Measurement of Aqueous Tear Production. Tear production was measured with the Schirmer test in each group at day 3 and day 10 after the first Con A injection, respectively (i.e., just before eye drop application and 7 days after onset of eye drop application).

Measurement of Conjunctival Goblet Cell Density. Impression cytology ${ }^{16}$ was performed in each group at day 3 and day 10 after the first Con A injection, respectively (i.e., just before eye drop application and 7 days after the onset of eye drop application). Cytology specimens were taken from the superior conjunctiva of each eye, and goblet cells were counted in 10 consecutive high-power fields (HPFs) after periodic acid-Schiff (PAS) reagent staining.
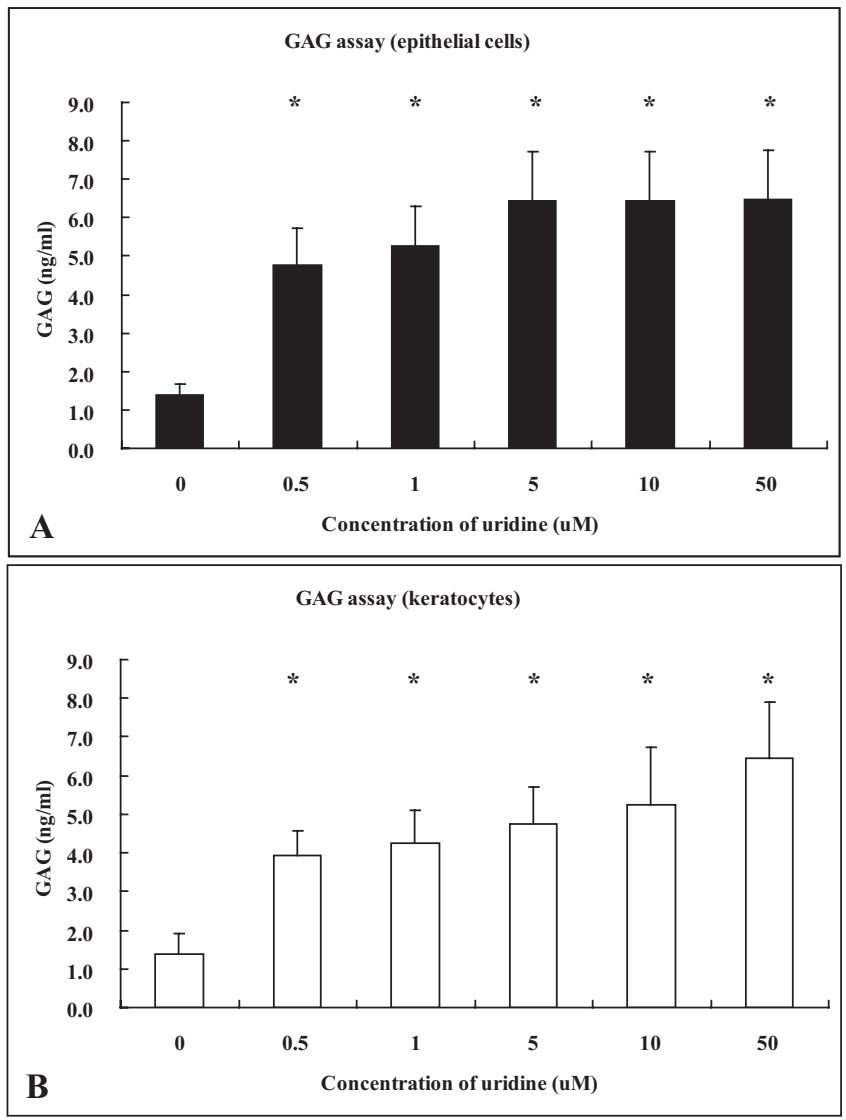

FIGURE 4. Glycosaminoglycan (GAG) biosynthesis assay using an enzyme-linked immunosorbent assay at various concentrations of uridine $(0.5-50.0 \mu \mathrm{M})$ in cultured epithelial cells (A) and keratocytes (B). GAG increased significantly in uridine-added epithelial cells and keratocytes at all the concentrations examined. Data are expressed as mean \pm SD. ${ }^{*} P<0.05$ (Student's $t$ test) 

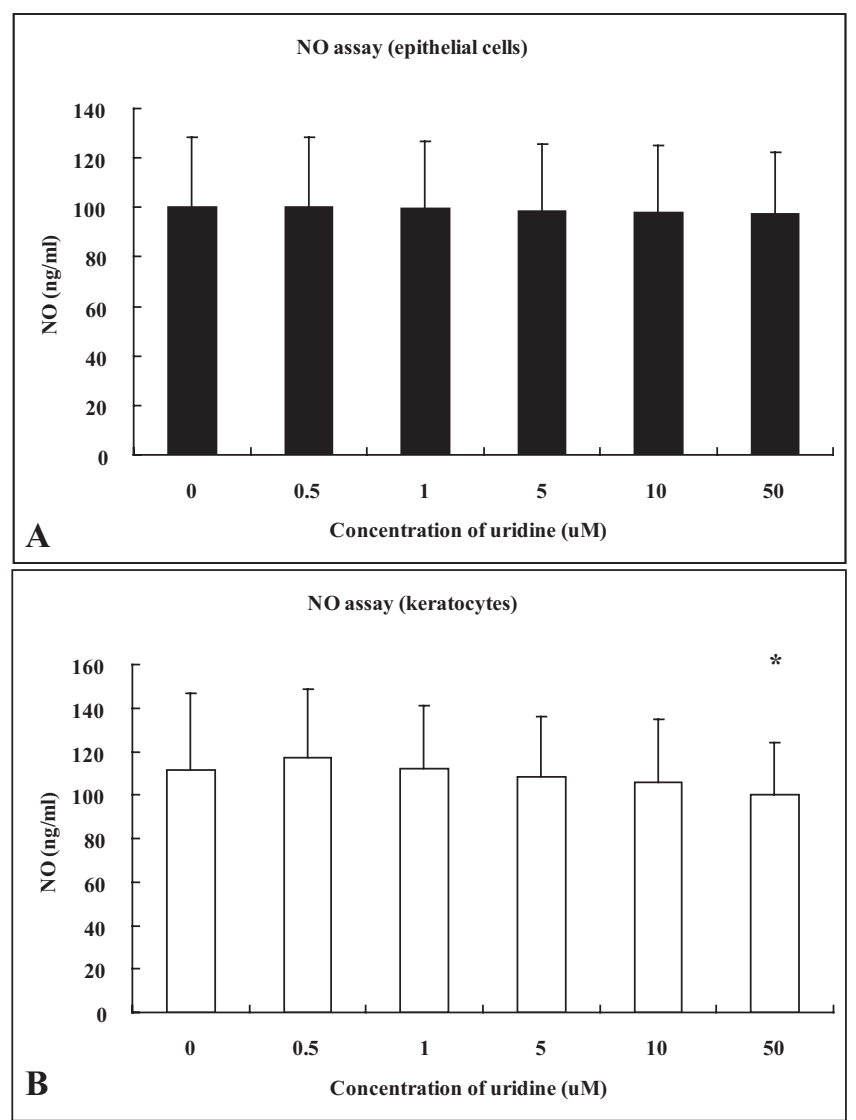

Figure 5. Nitric oxide (NO) assay using an enzyme-linked immunosorbent assay at various concentrations of uridine $(0.5-50.0 \mu \mathrm{M})$ in cultured epithelial cells (A) and keratocytes (B). NO decreased significantly at $50 \mu \mathrm{M}$ uridine in keratocytes, whereas the decrease in NO was not significant in epithelial cells. Data are expressed as mean $\pm \mathrm{SD}$. ${ }^{*} P<0.05$ (Student's $t$ test).

\section{Statistical Methods}

Within each group, temporal changes in tear amount and goblet cell counts were tested with the Student's $t$ test. The difference between pretreatment and posttreatment measurements in tear amount and goblet cell counts was obtained by subtracting measurements at day 3 from measurements at day 10 in each group; mean change was compared between the groups using a Kruskal-Wallis test. $P<0.05$ was considered statistically significant.

\section{RESUlTS}

\section{Effect of Uridine on Cultured Corneal Epithelial Cells and Keratocytes}

MTT assay revealed cell proliferation rather than cytotoxicity at all concentrations of uridine (0.1-100 $\mu \mathrm{M}$; Figs. 1A, 1B). No differences in apoptosis rates were observed between uridinetreated cells and untreated controls through flow cytometry of epithelial cells and keratocytes (Figs. 2A, 2B).

HA increased significantly in uridine-added epithelial cells and keratocytes. Concentrations of HA were $0.97 \mathrm{ng} / \mathrm{mL}$ in the control without uridine and increased to $2.55,2.69,2.87$, and $1.92 \mathrm{ng} / \mathrm{mL}$ in cultured epithelial cells at $1.0 \mu \mathrm{M}, 5.0 \mu \mathrm{M}, 10.0$ $\mu \mathrm{M}$, and $50.0 \mu \mathrm{M}$, respectively. The increase in HA was not dose dependent (Fig. 3A). In cultured keratocytes, the concentrations of $\mathrm{HA}$ at baseline were $4.29 \mathrm{ng} / \mathrm{mL}$ but increased to 8.56, 8.84, 9.82, and $11.64 \mathrm{ng} / \mathrm{mL}$ at $1.0 \mu \mathrm{M}, 5.0 \mu \mathrm{M}, 10.0 \mu \mathrm{M}$,

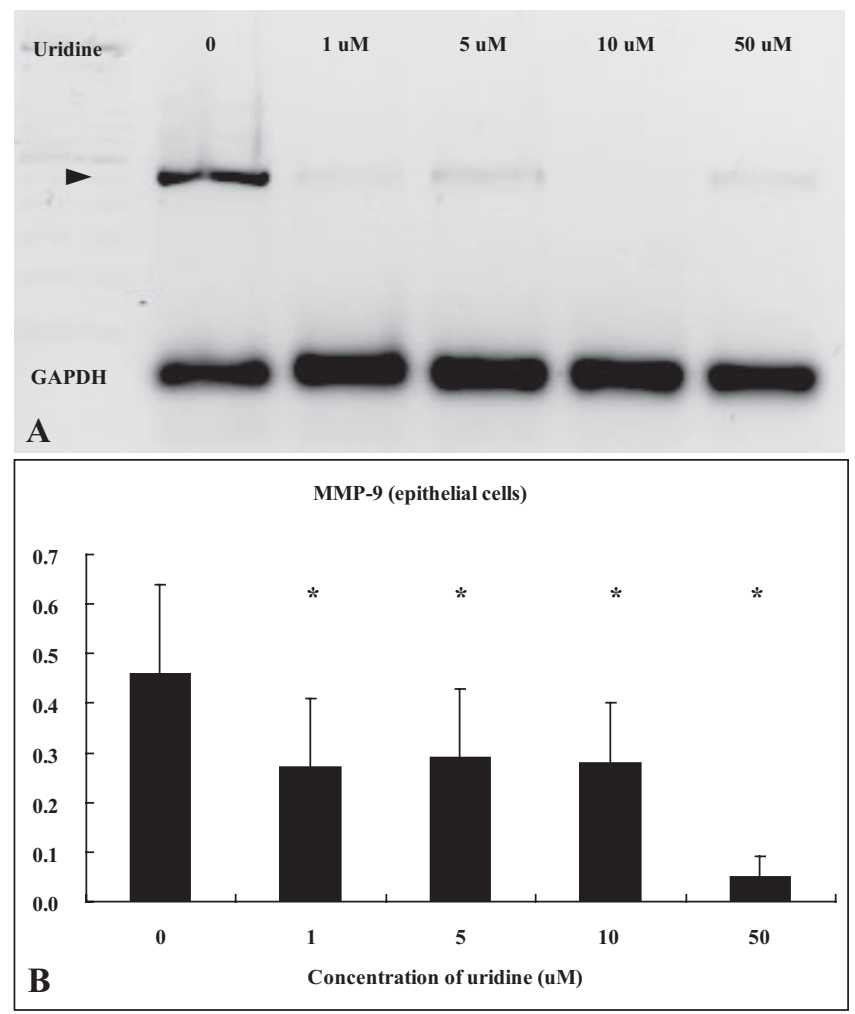

FIGURE 6. Reverse transcription-polymerase chain reaction analysis for MMP-9 mRNA in cultured epithelial cells (A). When quantified with densitometry, MMP-9 decreased at all applied concentrations of uridine in cultured epithelial cells, showing the highest reduction at $50.0 \mu \mathrm{M}$ (B). Data are expressed as mean $\pm \mathrm{SD} * P<0.05$ (Student's $t$ test).

and $50.0 \mu \mathrm{M}$, respectively (Fig. 3B). HA increased in a dosedependent manner in keratocytes.

GAG concentration also increased significantly with uridine. It was $1.38 \mu \mathrm{M}$ in the control without uridine and increased to $4.76 \mu \mathrm{M}, 6.45 \mu \mathrm{M}$, and $6.45 \mu \mathrm{M}$ in epithelial cells with $0.5 \mu \mathrm{M}, 5.0 \mu \mathrm{M}$, and $50.0 \mu \mathrm{M}$ uridine, respectively (Fig. 4A). In keratocytes, the concentrations of GAG were $3.92 \mu \mathrm{M}$, $4.76 \mu \mathrm{M}$, and $6.45 \mu \mathrm{M}$ when $0.5 \mu \mathrm{M}, 5.0 \mu \mathrm{M}$, and $50.0 \mu \mathrm{M}$ of uridine was added respectively, whereas it was $1.38 \mu \mathrm{M}$ when uridine was not added. GAG increase was dose dependent (Fig. 4B).

The application of uridine reduced NO production significantly at $50 \mu \mathrm{M}$, but only in keratocytes (Fig. 5). Uridine also decreased the expression of MMP-9 at all studied concentra-

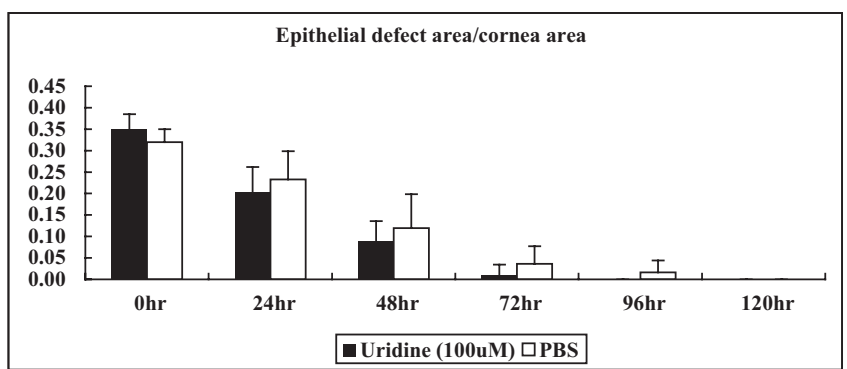

FIGURE 7. Assessment of reepithelialization in a rabbit corneal wound model with topical application of uridine $(100 \mu \mathrm{M})$. The ratio of epithelial defect area to total corneal area was calculated by an image analyzer. Corneal wound healing was more rapid in the eyes with uridine, compared with those in control group, though it was not statistically significant. Data are expressed as mean \pm SD. 


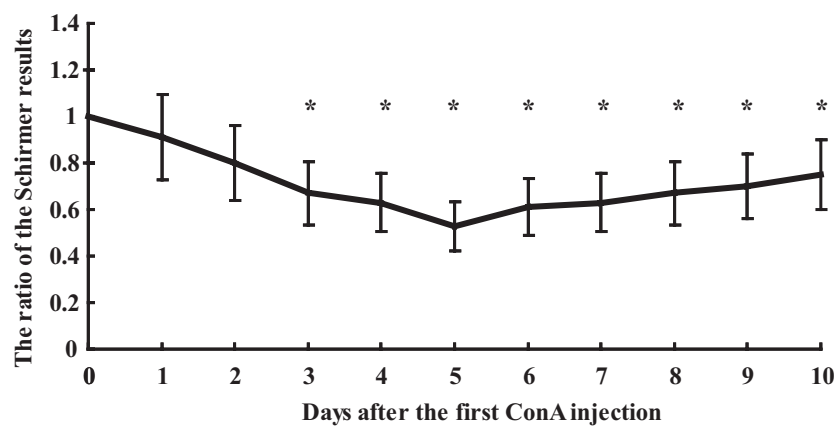

Figure 8. Measurement of tear production using the Schirmer test after Con A injection into the rabbit lacrimal gland $(n=20)$. Values of the Schirmer test on the days after Con A injection were divided by those at preinjection to eliminate the individual variation. Aqueous tear production was significantly decreased compared with baseline from day 3 to day 10 after injection. Data are expressed as mean \pm SD. ${ }^{*} P<$ 0.05 versus baseline before Con A injection.

tions in cultured epithelial cells and showed the highest reduction at $50 \mu \mathrm{M}$ (Fig. 6).

\section{Effect of Uridine on Corneal Wound Repair in a Rabbit Model}

Corneal wound healing was more rapid in the eyes treated with uridine $(100 \mu \mathrm{M})$ than in those in the control group; however, these results were not statistically significant (Fig. 7).

\section{Establishment of a Short-term Dry Eye Model in a Rabbit}

Aqueous tear production was significantly decreased compared with baseline on day 3 after injection, and this reduction was maintained until day 10 (Fig. 8). Aqueous tear production was fully recovered 10 days after the first injection of Con A (data not shown). The number of conjunctival goblet cells was also noticeably decreased on day 3 after injection, as measured by impression cytology (Figs. 9A, 9B). Histopathologic analysis of the lacrimal glands showed that many lymphocytes and inflammatory cells were infiltrated on day 3 after injection (Figs. 10A, 10B).

\section{Effect of Uridine in a Rabbit Dry Eye Model by Topical Application}

No significant differences in tear secretion were observed between treated eyes and controls before and after treatment $(P>0.05$; Table 1). Conjunctival goblet cell density, however, was significantly increased in the uridine-instilled eyes. Within each group, the number of goblet cells at day 10 significantly increased in the $5 \%$ uridine-treated eyes after treatment $(P=$
0.003; Student's $t$ test), $1 \%$ uridine eyes $(P=0.038), 10 \%$ uridine eyes $(P=0.012)$, and hyaluronic acid-treated eyes $(P=$ 0.022 ) compared with the values at day 3 before treatment. Among all groups, the increase in the number of goblet cells at day 10 from the values at day 3 was significant in 5\% and 10\% uridine-treated eyes compared with those in control eyes $(P<$ 0.001; Kruskal-Wallis test; Figs. 11, 12A, 12B).

\section{Discussion}

$\mathrm{HA}$ is a linear polymer of glucuronic acid $\mathrm{N}$-acetylglucosamine disaccharide molecules. It was originally discovered in the vitreous body of the eye but subsequently was found in most parts of the body, including the skin and the synovial fluid of joints. It has been demonstrated that an HA receptor, CD44, is expressed in corneal and conjunctival cells. ${ }^{17}$ HA promotes cell migration in vitro and can stabilize the ocular surface epithelial barrier, ${ }^{10,11}$ suggesting that it may be directly involved in the process of epithelial repair by means of the activation of CD $44 .{ }^{18}$ Many reports have attested to the effects of exogenous $\mathrm{HA}$ in producing a beneficial wound-healing outcome. In animal experiments, topically applied HA has been shown to accelerate skin wound healing in rats ${ }^{19,20}$ and hamsters. ${ }^{21}$ Corneal epithelial wound healing is also reported to be stimulated by exogenously applied HA. ${ }^{22}$ It has been proposed that HA may have a role in controlling localized inflammation often present in patients with keratoconjuctivitis sicca $^{12}$; the reported benefits of exogenously applied HA in tissue repair suggest that HA might be helpful on the ocular surface in patients with dry eye. The half-life of HA in keratinocytes in the epidermis, however, has been reported to be less than 1 day, whereas in the chondrocytes of cartilages it has been reported to be 2 to 3 weeks. Moreover, approximately one third of HA in the body is metabolized within 1 day, suggesting that exogenous HA may play a limited role in vivo. Uridine is transformed to UTP by uridine kinase, and UTP is used in the synthesis of HA in vivo. Elevated UDP-glucose contributes to an increase in the synthesis of HA. ${ }^{9}$ Therefore, exogenous UTP might possibly result in an increase of endogenous biosynthesis of HA. Furthermore, UTP is a $\mathrm{P}_{2} \mathrm{Y}_{2}$ receptor agonist, and $\mathrm{P}_{2} \mathrm{Y}_{2}$ receptor agonists such as UTP and $\mathrm{ATP}^{5}$ stimulate mucin secretion in vitro and in vivo in various tissues, such as conjunctiva, ${ }^{6}$ nasal epithelial cells, ${ }^{7}$ and tracheal gland cells. ${ }^{8}$ Mucin stimulants may be good candidates for dry eye treatment because mucin increases tear film stability and protects against desiccation of the ocular surface. We performed this study to evaluate the effect of uridine on the ocular surface of dry eye and to assess the possibility of uridine as a treatment for dry eye syndrome.

In this study, uridine had no cellular toxicity, and it increased the biosynthesis of HA and GAG. In corneal epithelial cells, HA increased even at a concentration as low as $1.0 \mu \mathrm{M}$

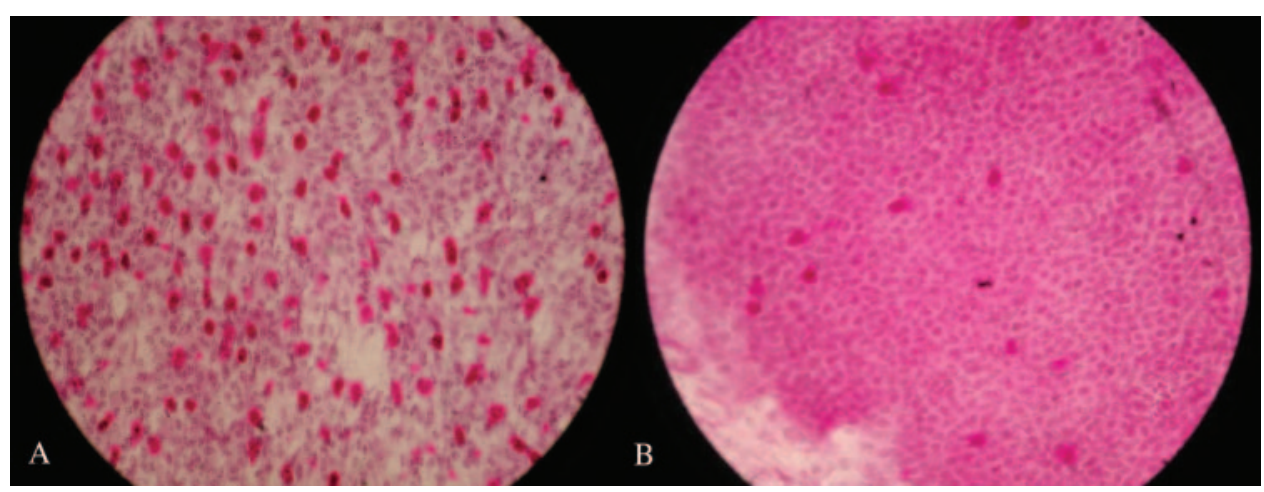

Figure 9. Goblet cell counts using impression cytology (PAS, $\times 200)$ at preinjection baseline (A) and at 3 days after Con A injection (B). Amount of conjunctival goblet cell was noticeably decreased on day 3 after injection. 
FIGURE 10. Histopathologic analysis of the lacrimal glands (H\&E; original magnification, $\times 100)$ at preinjection baseline (A) and 3 days after Con A injection (B). Marked inflammation was observed in the lacrimal gland after Con A injection.

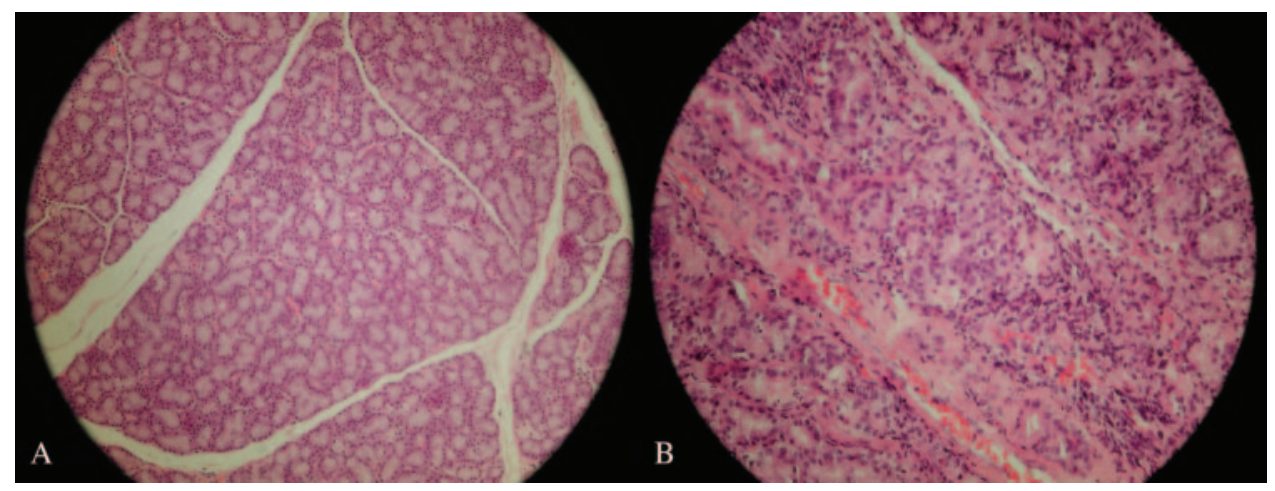

uridine; however, the increase of HA was not dose dependent at a high concentration of $50.0 \mu \mathrm{M}$. This might have been attributed to receptor anergy, ${ }^{23}$ suggesting that a high concentration of uridine is not necessary as a drug for dry eye and that pulse therapy using uridine might be more useful as a treatment regimen rather than as a continuous application. In this study, uridine also reduced MMP-9 in cultured corneal epithelial cells and keratocytes. MMP-9, as an activator of inflammatory cytokines such as TGF- $\beta 1$ and $\mathrm{IL}-1 \beta$, is known to be present at significantly higher levels in the tear fluid of patients with keratoconjunctivitis sicca. MMP-9 itself is a degradative enzyme and subsequently impedes the reepithelialization of the cornea. This uridine-induced decrease in MMP-9 might have been the reason for rapid wound healing of the rabbit cornea in our in vivo study. Alternatively, the in vivo dry eye animal model-or epithelial defect model-may represent stimulation of the cells by uridine to synthesize HA for wound healing. Another possibility is that the restoration of surface health, in the dry eye model, might be more closely associated with the $\mathrm{P}_{2} \mathrm{Y}_{2}$ receptor-related mechanism of uridine rather than HA synthesis. Therefore, another study in which the expression of hyaluronan synthase (HAS) 1, 2, or 3 or of $\mathrm{P}_{2} \mathrm{Y}_{2}$ receptor is investigated in uridine-treated cells is under way to reveal the mechanisms of the protective effect of uridine.

HA is known to have multiple roles in inflammation activation and moderation of keratocytes and fibroblasts. However, the roles of HA have been contradictory in reports on inflammation. The wound tissue, in the early inflammatory phase of wound repair, is rich in $\mathrm{HA}$, probably a reflection of increased synthesis. ${ }^{24}$ HA can act as a promoter of early inflammation that is important in the wound healing process. In a murine air pouch model of carrageenan/IL-1-induced inflammation, HA was shown to enhance cellular infiltration. ${ }^{25}$ Kobayashi and Terao $^{26}$ have shown a dose-dependent increase of the proinflammatory cytokines TNF- $\alpha$, IL- $1 \beta$, and IL- 8 production by human uterine fibroblasts through a CD44-mediated mechanism. HA also has an anti-inflammatory role by which it acts to decrease MMP in fibroblasts. One report shows that HA sup-

TABle 1. Schirmer Test Results before and at Various Time Points after Topical Uridine Application in a Rabbit Dry Eye Model

\begin{tabular}{lrrrr}
\hline First ConA & $\begin{array}{c}\mathbf{5 \%} \\
\text { Uridine } \\
(\boldsymbol{n}=\mathbf{2 0})\end{array}$ & $\begin{array}{c}\text { 1\% } \\
\text { Uridine } \\
(\boldsymbol{n}=\mathbf{5})\end{array}$ & $\begin{array}{c}\text { Hyalein } \\
(\boldsymbol{n}=\mathbf{1 0})\end{array}$ & Control \\
\hline Before & $11.6 \pm 2.1$ & $12.0 \pm 2.9$ & $12.6 \pm 1.3$ & $11.6 \pm 1.7$ \\
3 days after & $6.6 \pm 1.6$ & $7.0 \pm 1.8$ & $6.9 \pm 0.5$ & $7.2 \pm 0.7$ \\
10 days after & $12.8 \pm 1.8$ & $13.2 \pm 1.5$ & $13.4 \pm 1.8$ & $12.6 \pm 1.8$
\end{tabular}

As a control, no eye drops were administered in 20 rabbits. No significant changes occurred in tear secretion between the groups. Data are expressed as mean (millimeters) \pm SD presses the production of MMP-1 by rheumatoid synovial fibroblasts stimulated by the proinflammatory cytokines TNF- $\alpha$ and IL-1 $\beta$ through intercellular adhesion molecule-1 (ICAM-1) and through the downregulation of NF- $\kappa \mathrm{B}$ and $\mathrm{p} 38 .{ }^{27,28} \mathrm{HA}$ may participate in the negative feedback loop of inflammatory activation. TNF- $\alpha$, an important cytokine generated in inflammation, stimulates the expression of TSG-6 in fibroblasts and inflammatory cells. TSG-6, a hyaluronan-binding protein, also forms a stable complex with the serum proteinase inhibitor $I \alpha I$ with a synergistic effect on the latter plasmin-inhibitory activity. Plasmin is involved in activation of the proteolytic cascade of MMP and other proteinases leading to inflammatory tissue damage. Therefore, the action of the TSG- $6 / \mathrm{I} \alpha \mathrm{I}$ complex, which may be additionally organized by binding to HA in the extracellular matrix, may serve as a potent negative feedback loop to moderate inflammation and to stabilize the granulation tissue as healing progresses. ${ }^{29}$ Similarly, endothelial cells, in response to inflammatory cytokines such as TNF- $\alpha$ and IL- $1 \beta$, also synthesize HA. ${ }^{30}$ Each of the roles of HA, as an initiator or a moderator of inflammation, appears to be involved in different stages of wound healing. HA also has important functions in epithelial cells. ${ }^{18}$ The primary function of HA in the epidermis is to maintain the extracellular space and to provide an open, hydrated structure for the passage of nutrients. It is also implicated in the control of keratinocyte proliferation, which is essential in normal epidermal function and in reepithelialization during tissue repair. In healing skin wounds, HA is expressed at the wound margin in the connective tissue matrix and in collocating with CD 44 expression. ${ }^{24}$ In renal proximal tubular epithelial cells, HA attenuates TGF- $\beta 1$-mediated signal-

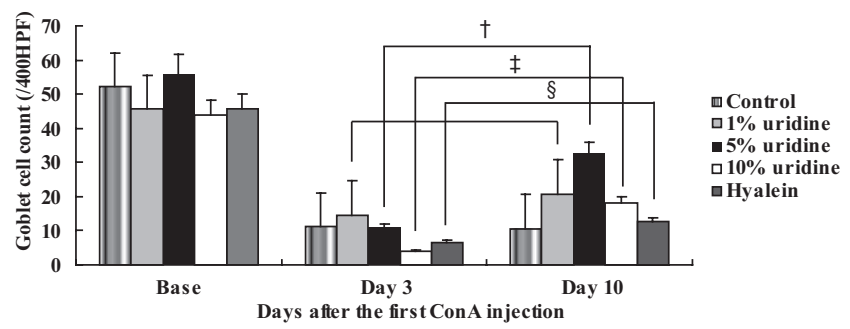

FIGURE 11. Conjunctival goblet cell counts before and at various time points after topical application in a rabbit dry eye model ( $n=20$ in the $5 \%$ uridine group, $n=5$ in the $1 \%$ and $10 \%$ uridine groups, $n=10$ in the hyaluronic acid group, and $n=20$ in the control group). Statistically significant differences were noticed in the study groups compared with the values before treatment. The greatest increase in goblet cell density was observed in the 5\% uridine group. Among all the groups, the degree of increase in goblet cell counts at day 10 from the values at day 3 was significant in the $5 \%$ and $10 \%$ uridine-treated groups compared with those in the control group $(P<0.001)$. Data are

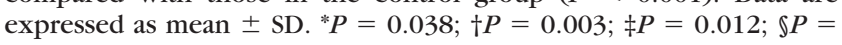
0.022 . 


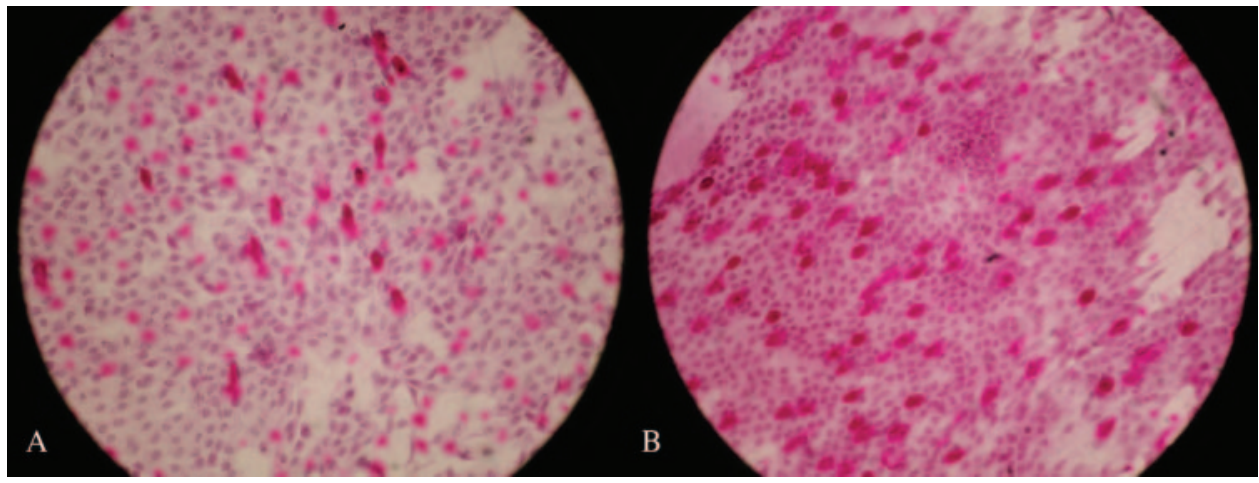

Figure 12. Goblet cell counts using impression cytology (PAS, $\times 200$ ) before (A) and after (B) 7 days of $5 \%$ uridine eye drops application. Marked increase in the number of conjunctival goblet cells was observed. ing, critical to the development of progressive renal disease. ${ }^{31}$ In corneal epithelial cells, it promotes migration in vitro. ${ }^{32}$ In our study, the expression of MMP was decreased in corneal epithelial cells when uridine was added, possibly because of the anti-inflammatory nature of HA. Given that MMP-9 level alone could not represent the anti-inflammatory action of uridine, further study is required to evaluate inflammatory cytokines or inflammatory cells for anti-inflammatory action of uridine on the cornea. In addition, we cannot yet explain the exact mechanism by which MMP is decreased by HA in epithelial cells. It may be possible through the inhibition of ICAM-1 interaction ${ }^{27,28}$ or through changes in cytokines, such as IL-8 and IL-10. ${ }^{33}$ More study is needed to investigate this mechanism.

In a short-term dry eye model using the rabbit, we found that topical application of uridine increased the number of conjunctival goblet cells, and 5\% uridine eye drops demonstrated the best effect on increasing the goblet cell counts. This effect of uridine on goblet cell counts suggests that uridine may possibly work as a $\mathrm{P}_{2} \mathrm{Y}_{2}$ receptor agonist, leading to increased mucin secretion. Another possibility is that uridine may rapidly restore the health of the ocular surface by increasing internal HA synthesis or by reducing inflammation as in the in vivo dry eye model. Schirmer test results in this study favored the latter hypothesis.

In conclusion, the results of this study demonstrated that uridine could restore the health of the ocular surface rapidly, possibly because of an increase in internal HA synthesis, reduction in the amount of degradative enzyme such as MMP-9, or enhancement of the number of goblet cells. We are now investigating the action of uridine as a $\mathrm{P}_{2} \mathrm{Y}_{2}$ receptor agonist and as a hyaluronate promoter.

\section{References}

1. Schein OD, Munoz B, Tielsch JM, Bandeen-Roche K, West S. Prevalence of dry eye among the elderly. Am J Ophthalmol. 1997; 124:723-728.

2. Moss SE, Klein R, Klein BE. Prevalence of and risk factors for dry eye syndrome. Arch Ophthalmol. 2000;118:1264-1268.

3. Yokoi N, Komuro A. Nishida K, Kinoshita S. Effectiveness of hyaluronan on corneal epithelial barrier function in dry eye. $\mathrm{BrJ}$ Ophthalmol. 1997;81:533-5336.

4. Aragona P, Papa V, Micali A, Santocono M, Milazzo G. Long term treatment with sodium hyaluronate-containing artificial tears reduces ocular surface damage in patients with dry eye. $\mathrm{BrJ} O \mathrm{Op}$ thalmol. 2002;86:181-184.

5. Ralevic V, Burnstock G. Receptors for purines and pyrimidines. Pharmacol Rev. 1998;50:4133-4192.

6. Jumblatt JE, Jumblatt MM. Regulation of ocular mucin secretion by $\mathrm{P}_{2} \mathrm{Y}_{2}$ nucleotide receptors in rabbit and human conjunctiva. Exp Eye Res. 1998;67:341-346.

7. Choi JY, Namkung W, Shin JH, Yoon JH. Uridine-5'-triphosphate and adenosine triphosphate gammaS induce mucin secretion via
$\mathrm{Ca}^{+}$-dependent pathways in human nasal epithelial cells. Acta Otolaryngol. 2003;123:1080-1086.

8. Merten MD, Saleh A, Kammouni W, Marchand S, Figarella C. Characterization of two distinct $\mathrm{P} 2 \mathrm{Y}$ receptors in human tracheal gland cells. Eur J Biochem. 1998;251:19-24.

9. Magee C, Nurminskaya M, Linsenmayer TF. UDP-glucose pyrophosphorylase: up-regulation in hypertrophic cartilage and role in hyaluronan synthesis. Biochem J. 2001;360:667-674.

10. Rosales C, O'Brien V, Kornberg L, Juliano R. Signal transduction by cell adhesion receptors. Biochem Biophys Acta. 1995;1242:77-98.

11. Nishida T, Nakamura M, Mishima H, Otori T. Hyaluronan stimulates corneal epithelial migration. Exp Eye Res. 1991;53:753-758.

12. Stern ME, Beuerman RW, Fox RI, Gao J, Mircheff AK, Pflugfelder SC. The pathology of dry eye: the interaction between the ocular surface and lacrimal gland. Cornea. 1998;17:584-589.

13. Li DQ, Tseng SC. Three patterns of cytokine expression potentially involved in epithelial-fibroblast interactions of human ocular surface. J Cell Physiol. 1995;163:61-79.

14. Li DQ, Lokeshwar BL, Solomon A, Monroy D, Ji Z, Pflugfelder SC. Regulation of MMP-9 production by human corneal epithelial cells. Exp Eye Res. 2001;73:449-459.

15. Nagelhout TJ, Gamache DA, Roberts L, Brady MT, Yanni JM. Preservation of tear film integrity and inhibition of corneal injury by dexamethasone in a rabbit model of lacrimal gland inflammation-induced dry eye. J Ocul Pharmacol Ther. 2005;21:139-148.

16. Tseng SC. Staging of conjunctival squamous metaplasia by impression cytology. Ophthalmology. 1985;92:728-733.

17. Lerner LE, Schwartz DM, Hwang DG, Howes EL, Stern R. Hyaluronan and CD44 in the human cornea and limbal conjunctiva. Exp Eye Res. 1998;67:481-484.

18. Chen WY, Abatangelo G. Functions of hyaluronan in wound repair, Wound Repair Regeneration. 1999;7:79-89.

19. Abatangelo G, Martelli M, Vecchia P. Healing of hyaluronic acidenriched wounds: histological observations. J Surg Res. 1983;35: $410-416$

20. Foschi D, Castoldi L, Radaelli E, et al. Hyaluronic acid prevents oxygen free-radical damage to granulation tissue: a study in rats. Int J Tiss React. 1990;12:333-339.

21. King SR, Hickerson WL, Proctor KG, Newsome AM. Beneficial actions of exogenous hyaluronic acid on wound healing. Surgery. 1991;109:76-84.

22. Nakamura M, Hikida M, Nakano T. Concentration and molecular weight dependency of rabbit corneal epithelial wound healing on hyaluronan. Curr Eye Res. 1992;11:981-986.

23. Klepeis VE, Weinger I, Kaczmarek E, Trinkaus-Randall V. P2Y receptors play a critical role in epithelial cell communication and migration. Cell Biochem . 2004;3:1115-1133.

24. Oksala O, Salo T, Tammi R, et al. Expression of proteoglycans and hyaluronan during wound healing. J Histochem Cytochem. 1995; 43:125-135.

25. Wisniewski HG, Hua JC, Poppers DM, Naime D, Vilcek J, Cronstein BN. TNF/IL-1-inducible protein TSG-6 potentiates plasmin inhibition by inter- $\alpha$-inhibitor and exerts a strong anti-inflammatory effect in vivo. J Immunol. 1996;156:1609-1615. 
26. Kobayashi H, Terao T. Hyaluronic acid-specific regulation of cytokines by human uterine fibroblasts. Am J Physiol. 1997;276: C1151-C1159.

27. Hiramitsu $\mathrm{T}$, Yasuda $\mathrm{T}$, Ito $\mathrm{H}$, et al. Intercellular adhesion molecule-1 mediates the inhibitory effects of hyaluronan on interleukin$1 \beta$-induced matrix metalloproteinase production in rheumatoid synovial fibroblasts via down-regulation of NF- $\kappa \mathrm{B}$ and $\mathrm{p} 38$. Rheumatology. 2006; 45:824-832.

28. Shimizu M, Yasuda T, Nakagawa $T$, et al. Hyaluronan inhibits matrix metalloproteinase-1 production by rheumatoid synovial fibroblasts stimulated by proinflammatory cytokines. J Rheumatol. 2003;30:1164-1172.

29. Wisniewski HG, Vilcek J. TSG-6: an IL-1/TNF-inducible protein with anti-inflammatory activity. Cytokine Growth Factor Rev. 1997;8:143-156.
30. Mohamadzadeh M, DeGrendele H, Arizpe H, Estess P, Siegelman M. Proinflammatory stimuli regulate endothelial hyaluronan expression and CD44/HA-dependent primary adhesion.J Clin Invest. 1998;101:97-108.

31. Ito T, Williams JD, Fraser D, Phillips AO. Hyaluronan attenuates transforming growth factor-beta1-mediated signaling in renal proximal tubular epithelial cells. Am J Patbol. 2004;164:16791688.

32. Gomes JA, Amankwah R, Powell-Richards A, Dua HS. Sodium hyaluronate (hyaluronic acid) promotes migration of human corneal epithelial cells in vitro. Br J Ophthalmol. 2004;88:821-825.

33. Boodoo S, Spannhake EW, Powell JD, Horton MR. Differential regulation of hyaluronan-induced IL-8 and IP-10 in airway epithelial cells. Am J Physiol Lung Cell Mol Physiol. 2006;291:L479L486. 